\title{
Biogas Production from Raw Digestate and its Fraction
}

\author{
Wojciech Czekała'
}

\author{
1 Poznan University of Life Sciences, ul. Wojska Polskiego 28, 60-637 Poznań, Poland \\ e-mail: wojciech@up.poznan.pl
}

\begin{abstract}
The digestate from an agricultural biogas plant is most commonly used as a fertilizer. However, many studies are being performed to develop other ways of managing this substrate. The aim of this study was to determine the biogas and methane efficiency for digestate as well as the solid and liquid fractions from separation of digestate. The material for the research came from a real scale agricultural biogas plant. The separation of the digestate into two fractions was carried out using a mechanical press. The studies on the methane fermentation process were carried out under mesophilic conditions $\left(37-39^{\circ} \mathrm{C}\right)$ in the Institute of Biosystems Engineering at the Poznań University of Life Sciences. It was found that the biogas and methane efficiency for the raw digestate and liquid fraction obtained from its separation is very low. For raw digestate it was $2.9 \mathrm{~m}^{3}$ of biogas from $1 \mathrm{Mg}$ fresh matter (FM), including $1.58 \mathrm{~m}^{3}$ methane. For liquid fraction after separation, the biogas efficiency amounted to $1.52 \mathrm{~m}^{3}$ from $1 \mathrm{Mg}$, including $0.78 \mathrm{~m}^{3}$ of methane. In turn, for the solid fraction, the biogas efficiency was $102.93 \mathrm{~m}^{3} \cdot \mathrm{Mg}^{-1}$, including $54.99 \mathrm{~m}^{3} \cdot \mathrm{Mg}^{-1}$ of methane. The research results indicate that the possibility of using the digestate solid fraction for energy production (e.g. secondary methane fermentation) or the production of solid biofuels.
\end{abstract}

Keywords: digestate, digested pulp, agricultural biogas plants, anaerobic digestion, waste management, renewable energy sources, circular economy.

\section{INTRODUCTION}

One of the types of renewable energy sources (RES) is the biogas produced in agricultural biogas plants, allowing to produce stable energy (Czekała, 2017). Therefore, the number of functioning biogas plants has been growing all over the world for many years. In addition to the choice of substrates and the technology of anaerobic digestion, more and more attention is paid to the problems of digestate management, i.e. the second product of the methane fermentation process. (Dahlin et al., 2017).

In the case of Poland, there is currently no definition of digestate in legislation, which creates problems in its management. Regardless, most frequently the digestate is defined as any non-degraded residue in the anaerobic digestion process. After meeting the requirements, the product generated in agricultural biogas plants can be treated as a waste, by-product as well as organic fertilizer (Act of December 14, 2012 On Waste, Regulation of the Minister for the Environment). Regardless of the legal aspects, the methods for further management of the substrate are the same.

During the fermentation process, only part of the compounds contained in the substrates is decomposed. As a result, digestate contains primarily water, undecomposed organic compounds and mineral compounds. For this reason, the type of substrates has an important influence on the properties of digestate and its use (Tampio et al., 2015).

Due to the high concentration of nutrients, raw digestate is most often used as a fertilizer. For this reason, pretreatment it not required and digestate can be applied directly on the fields. On the other hand, solid-liquid separation creates other opportunities for product utilization (Ronga et al., 2019). The liquid fraction is characterized by low dry matter and is used in fertilization or for hydration of biogas plant feed, which often occurs in the form of a solid substrate - for example silage. In contrast, the solid fraction can be used in many other ways for instance as fertilizer or energy source. Due to the fact that only a part of the organic matter is degraded in biological 
processes, the remaining part can be used as a fertilizer enriching the soil, primarily in organic matter (Neugebauer, 2018). Another solution could be the addition of solid fraction to sewage sludge from small installations that do not have on-site sludge treatment facilities for co-composting (Sowińska et. al. 2018, Zaborowicz et al., 2018). Even a solid fraction without additives can be used to produce composts. In addition, the discussed fraction can be used for the production of solid biofuels, as evidenced by our own research, as well as by other authors (Czekała et al., 2018a, 2018b, Kratzeisen et al., 2010). A new direction for the use of solid fraction may involve its use in thermal processes, including the biochar production process (Latawiec et al., 2017) for example with biological pretreatment in the form of biodrying (Białowiec et al., 2015). Taking into account that agricultural biogas plants often do not have multi-stage fermentation, it was decided to analyze the biogas efficiency of the produced digestate. The aim of this research was to determine the biogas and methane efficiency of raw digestate as well as the solid and liquid fractions resulting from its separation.

\section{MATERIALS AND METHODS}

\section{Research object}

The analyzed material in this research involved the digestate from a selected agricultural biogas plant with the power output of over $1 \mathrm{MW}_{\mathrm{el}}$. The substrates used for the production of biogas were mainly maize silage, slurry as well as waste and pomace from fruits and vegetables. Apart from raw digestate, two fractions resulting from the separation of digestate - a solid fraction and a liquid fraction - were also used in this research. The test samples were delivered to the Institute of Biosystem Engineering under thermal insulation conditions to prevent their biodegradation. The properties of the fractions were shown in table 1 .
The total solids was determined with a drying method at a temperature of $105^{\circ} \mathrm{C}$ for 24 hours, and volatile total solids was determined by the loss on ignition in a muffle furnace (temperature $550^{\circ} \mathrm{C}$ for $3 \mathrm{~h}$ ). All measurements were made in three repetitions.

\section{Laboratory methane fermentation system}

The raw digestate and its fractions were tested to check their biogas and methane efficiency. The experiment was carried under anaerobic digestion conditions $\left(37^{\circ} \mathrm{C}-39^{\circ} \mathrm{C}\right)$ in the 21 -chamber biofermentor set at the Laboratory of Ecotechnology in the Institute of Biosystems Engineering of Poznan University of Life Sciences (Fig. 1). The biogas and methane efficiency were tested using the German DIN 38414/S8 and VDI 4630 VDI-Gesellschaft Energietechnik standards. Anaerobic digestion experiments were carried out in the stirred tank reactors made of glass. These research methods are commonly used in biogas production laboratory research (Kozłowski et al. 2018). The inoculum for the solid fraction of digestate was the liquid fraction containing microorganisms necessary for anaerobic digestion. Every day, the volume of biogas produced and its qualitative composition were checked using the GeoTech gas analyzer GA5000. A detailed methodology used in the production of biogas was described in the article by Cieślik et al., (2016).

\section{RESULTS AND DISCUSSION}

The digestate from the agricultural biogas plant cannot be completely fermented in the main fermentation chamber. This is due to the fact that the rate of fermentation decreases over time. This is confirmed i.a. by figures $2-4$. Therefore, it is recommended to build a minimum of two digester chambers allowing for the production and storage of biogas.

Table 1. Selected parameters of raw digestate and its fractions

\begin{tabular}{|c|c|c|c|c|}
\hline \multirow{2}{*}{ Sample } & \multicolumn{5}{|c|}{ Initial parameters } \\
\cline { 2 - 5 } & $\mathrm{pH}$ & conductivity $\left[\mathrm{mS} \cdot \mathrm{cm}^{-1}\right]$ & total solids [\% FM] & volatile total solids [\% TS] \\
\hline Raw digestate & 7.77 & 20.10 & 3.57 & 71.42 \\
\hline Liquid fraction & 7.93 & 20.4 & 2.97 & 67.42 \\
\hline Solid fraction & 9.99 & 1.19 & 30.66 & 95.74 \\
\hline
\end{tabular}




\section{Daily biogas production and fermentation time for substrates}

The characteristics of daily biogas and methane production for raw digestate were varied, as evidenced by the data presented in Figure 2 . The highest daily biogas production amounted to $0.37 \mathrm{dm}^{3}$ took place on the second day, and the high level of methane production was continued until the seventh day. In turn, the lowest daily biogas production at the level of $0.06 \mathrm{dm}^{3}$ was observed on the nineteenth day. In the following days, daily production was varied, but did not exceed $0.20 \mathrm{dm}^{3}$ of biogas daily production. The experiment was finished on the thirty second day, according to the methodology (modified German DIN 38,414/S8 and VDI 4630 standards).
The daily biogas production, including methane for the liquid fraction, was shown in Figure 3. The highest daily production of biogas and methane occurred on the first days of the experiment. The highest biogas production took place on the second and third day, reaching $0.14 \mathrm{dm}^{3}$, including about $0.05 \mathrm{dm}^{3}$ of methane. From the tenth day, the production of biogas and methane was characterized by a large diversity, without a clear trend. The methane fermentation process was finished after twenty-six days.

The trend of the daily production of methane and biogas for a solid fraction was practically unidirectional throughout the duration of the experiment. The maximum values occurred on the second and fourth day, while the production of biogas and methane reached a very high level, exceeding $1.20 \mathrm{dm}^{3}$ and $0.60 \mathrm{dm}^{3}$, respectively.
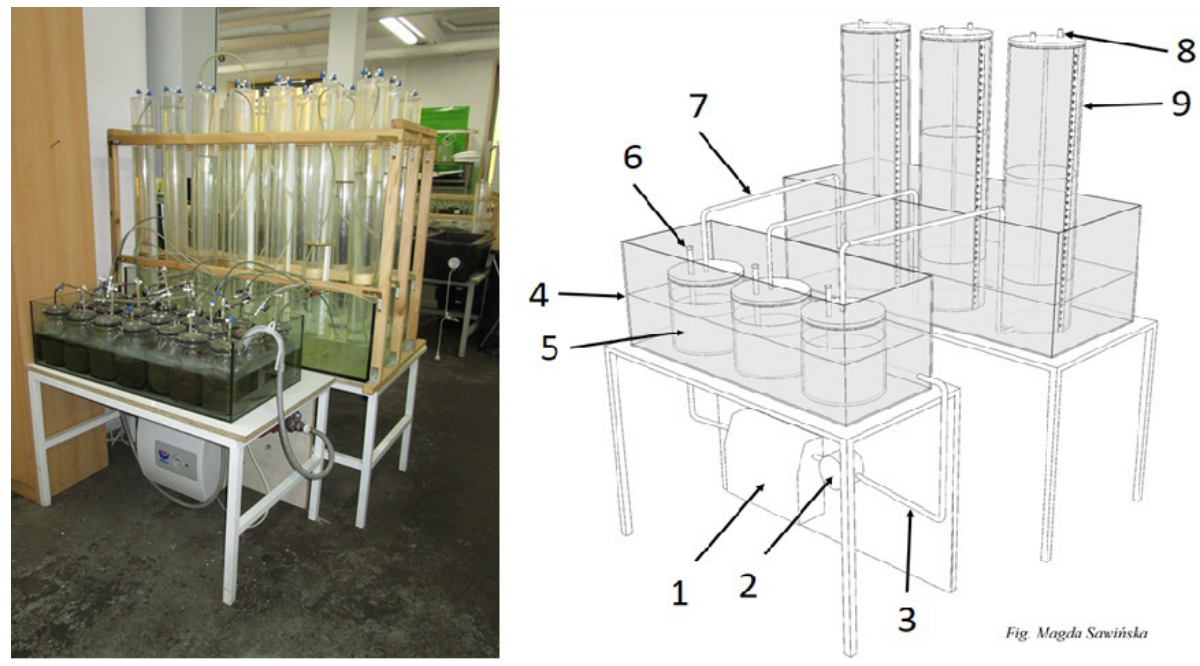

Fig. 1. The scheme of the biofermentor for biogas production research 3-chamber section: 1 - water heater with temperature regulator, 2 - water pump, 3 - insulated conductors of calefaction liquid, 4 - water coat with temp. $39^{\circ} \mathrm{C}, 5$ - biofermentor with charge capacity of $2 \mathrm{dm}^{3}, 6$ - sampling tubes, 7 - biogas transporting tube, 8 - gas sampling valve, 9 - biogas volume-scale reservoir

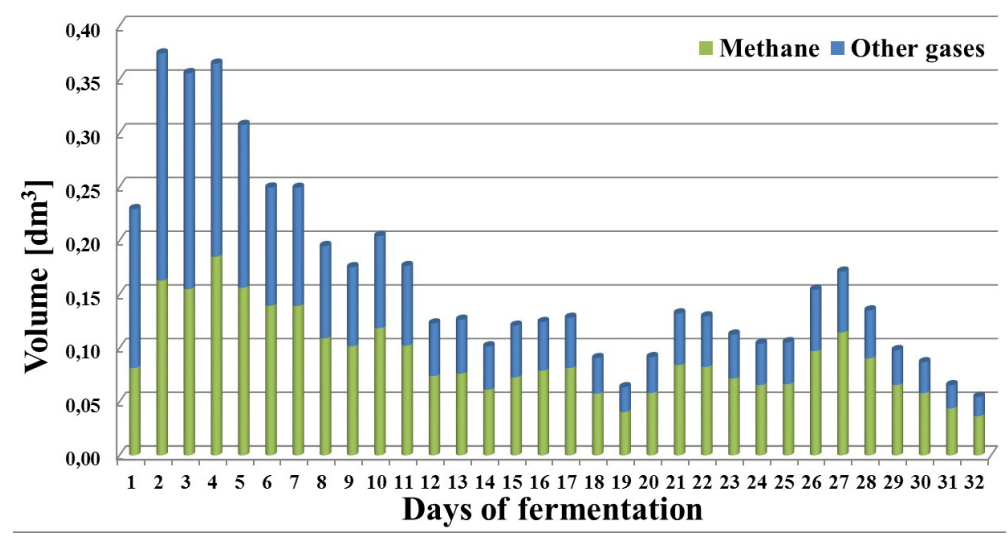

Fig. 2. Daily biogas and methane production for raw digestate 


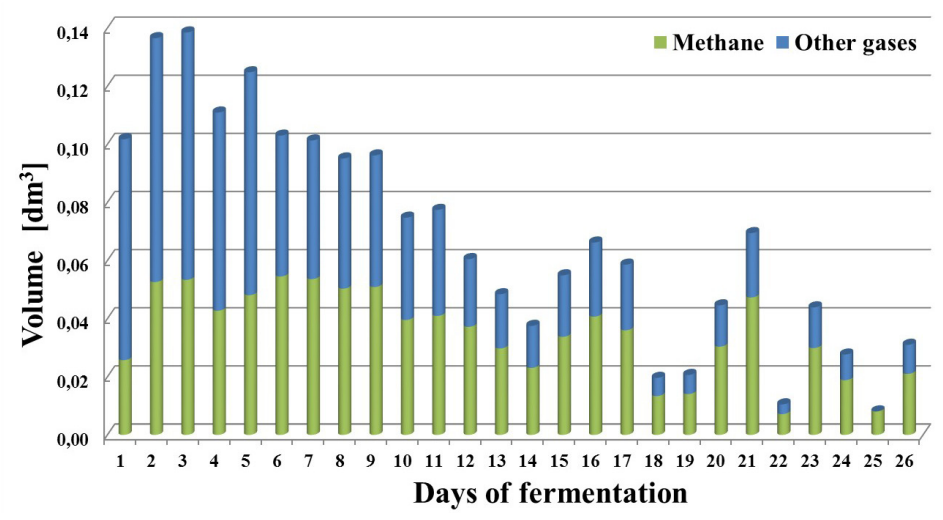

Fig. 3. Daily biogas and methane production for liquid fraction of digestate

From the eighth day onward, a slow but systematic decrease in the daily production was observed, lasting until the thirty-sixth day of the experiment, when methane production reached $0.11 \mathrm{dm}^{3}$ and biogas amounted for $0.17 \mathrm{dm}^{3}$ (Fig. 4).

\section{Methane and biogas efficiency}

Table 2 presents the biogas and methane efficiency of the analyzed digestate and its fraction after the separation process. Due to the substrate division into dry and organic matter, the results were presented in terms of fresh matter, total solids and dry matter and volatile solids.

The concentration of methane in biogas was similar in all three samples tested and ranged from $51.13 \%$ for liquid fraction to $54.60 \%$ for raw digestate exhibiting low energy potential. Biogas efficiency calculated as FM was $2.9 \mathrm{~m}^{3} \cdot \mathrm{Mg}^{-1}$, and methane was $1.58 \mathrm{~m}^{3} \cdot \mathrm{Mg}^{-1}$. Even lower values were characterized by a liquid fraction, for which the biogas yield amounted for $1.52 \mathrm{~m}^{3} \cdot \mathrm{Mg}^{-1}$, and methane gas was $0.78 \mathrm{~m}^{3} \cdot \mathrm{Mg}^{-1}$. Solid fraction was characterized by different results, as evidenced by the data presented in table 2 . The biogas efficiency of the analyzed fraction was $102.93 \mathrm{~m}^{3} \cdot \mathrm{Mg}^{-1}$, with methane concentration of $53.42 \%$ methane efficiency reached $54.99 \mathrm{~m}^{3} \cdot \mathrm{Mg}^{-1}$.

Usually, substrates with high dry matter content have a higher biogas efficiency, as exemplified by maize silage. For example, in the Cieślik et al., studies (2016) maize silage with TS $46.06 \%$ was characterized by $204.06 \mathrm{~m}^{3} \cdot \mathrm{Mg}^{-1}$ biogas efficiency under thermophilic conditions. However, in the studies by Wojcieszak et al., (2018) maize straw silage with TS $61.10 \%$ was characterized by lower biogas efficiency $-141.78 \mathrm{~m}^{3} \cdot \mathrm{Mg}^{-1}$ under mesophilic conditions. Therefore, it was a higher value than the analyzed solid fraction characterized by $30.66 \%$ TS.

Węglarzy et al. (2017) showed that the stored solid manure was characterized by a biogas efficiency of $100 \mathrm{~m}^{3} \cdot \mathrm{Mg}^{-1}$ for dry matter $25.25 \%$ similar to solid fraction of analyzed digested pulp (tab. 2). The two mentioned substrates (manure and maize silage) are often used in agricultural

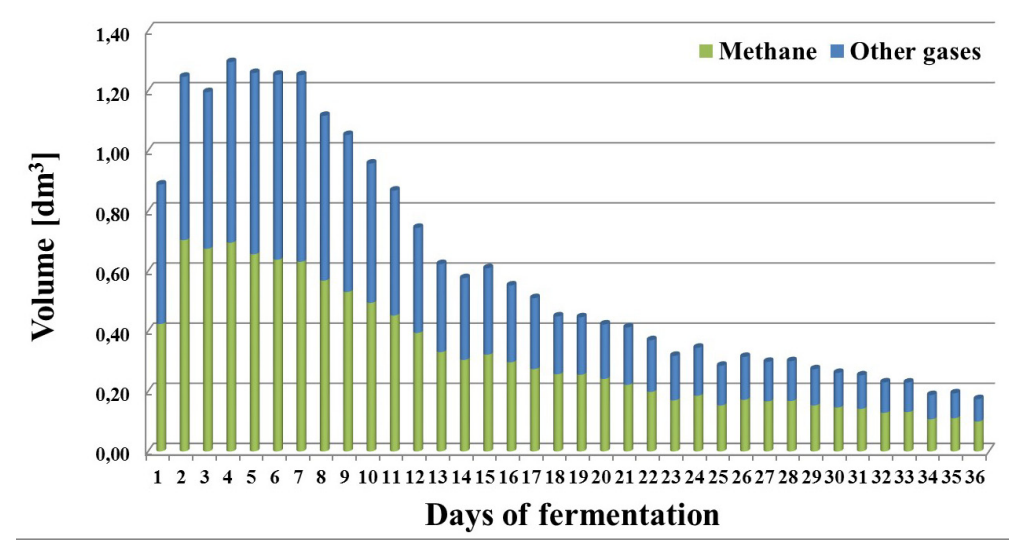

Fig. 4. Daily biogas and methane production for solid fraction of digestate 
Table 2. Biogas and methane efficiency of digestate and its fractions (FM - fresh mass, TS - total solids, VS - volatile solids)

\begin{tabular}{|c|c|c|c|c|c|c|c|}
\hline \multirow{2}{*}{ Sample } & $\begin{array}{c}\text { Methane } \\
\text { content } \\
{[\%]}\end{array}$ & \begin{tabular}{c} 
Fresh matter \\
\cline { 3 - 7 } \\
biogas \\
{$\left[\mathrm{m}^{3} \cdot \mathrm{Mg}^{-1}\right]$}
\end{tabular} & $\begin{array}{c}\text { Cumulative } \\
\text { methane } \\
{\left[\mathrm{m}^{3} \cdot \mathrm{Mg}^{-1}\right]}\end{array}$ & $\begin{array}{c}\text { Cumulative } \\
\text { biogas } \\
{\left[\mathrm{m}^{3} \cdot \mathrm{Mg}^{-1}\right]}\end{array}$ & $\begin{array}{c}\text { Cumulative } \\
\text { methane } \\
{\left[\mathrm{m}^{3} \cdot \mathrm{Mg}^{-1}\right]}\end{array}$ & $\begin{array}{c}\text { Cumulative } \\
\text { biogas } \\
{\left[\mathrm{m}^{3} \cdot \mathrm{Mg}^{-1}\right]}\end{array}$ & $\begin{array}{c}\text { Cumulative } \\
\text { methane } \\
{\left[\mathrm{m}^{3} \cdot \mathrm{Mg}^{-1}\right]}\end{array}$ \\
\hline $\begin{array}{c}\text { Raw } \\
\text { digestate }\end{array}$ & 54.60 & 2.90 & 1.58 & 81.19 & 44.33 & 113.68 \\
\hline $\begin{array}{c}\text { Liquid } \\
\text { fraction }\end{array}$ & 51.13 & 1.52 & 0.78 & 51.26 & 26.21 & 76.46 \\
\hline $\begin{array}{c}\text { Solid } \\
\text { fraction }\end{array}$ & 53.42 & 102.93 & 54.99 & 335.66 & 179.31 & 350.58 \\
\hline
\end{tabular}

biogas plants. Comparing them with the results of a digestate solid fraction, it can be concluded that this substrate can be successfully used in biogas plants, as evidenced by its biogas efficiency and methane content.

The obtained results confirm that the solid fraction of digestate is characterized by high energy potential and can be used as a substrate for the production of biogas, in contrast to the liquid fraction. However, it is necessary to perform preliminary research on the substrates from specific installations, because the degree of fermentation may be different for each of biogas plant, due to various biogas production technologies.

\section{CONCLUSION}

Digestate is one of the products in agricultural biogas plants; it is mainly used as a fertilizer. However, many studies are being performed on its alternative management. The installation owners wanting to limit financial outlays often do not implement multistage fermentation, which in turn causes a loss of the energy potential of the processed biomass. For this reason, the use of solid fraction of digested pulp in the secondary stage of biogas production is an alternative solution to solve its management process.

\section{Acknowledgements}

This work was supported by Human Capital Operational Programme, Sub-measure 8.2.2, cofinanced by the European Union under the European Social within the period of 2012-2013 (POKL 8.2.2/30-404-12/13) and 2013-2014 (PO KL 8.2.2/30-355-13/14). The research project "Scholarship support for PH.D. students specializing in majors strategic for Wielkopolska's development".

\section{REFERENCES}

1. Act Of 14 December 2012 On Waste (Dz.U. 2013 poz. 21).

2. Białowiec A., Wiśniewski D., Pulka J., Siudak M., Jakubowski B., Myślak B. Biosuszenie pofermentu $\mathrm{z}$ biogazowni rolniczych. Annual Set the Environment Protection 2015; 17: 1554-1568.

3. Cieślik M., Dach J., Lewicki A., Smurzyńska A., Janczak D., Pawlicka-Kaczorowska J., Boniecki P., Cyplik P., Czekała W., Jóżwiakowski K. Methane fermentation of the maize straw silage under meso- and thermophilic conditions. Energy 2016;115(2):1495-1502.

4. Czekała W., Dach J., Dong R., Janczak D., Malińska K., Jóźwiakowski K., Smurzyńska A., Cieślik M. 2017. Composting potential of the solid fraction of digested pulp produced by a biogas plant. Biosystems Engineering 160, 25-29.

5. Czekała W., Bartnikowska S., Dach J., Janczak D., Smurzyńska A., Kozłowski K., Bugała A., Lewicki A., Cieślik M., Typańska D., Mazurkiewicz J. 2018a. The energy value and economic efficiency of solid biofuels produced from digestate and sawdust. Energy 159, 1118-1122.

6. Czekała W., Janczak D., Wojcieszak D., Waliszewska H., Lewicki A., Smurzyńska A. 2018b. Nutrient value of digestate from agricultural biogas plant in Poland. Proceedings of 2018 2nd International Conference on Green Energy and Applications ICGEA 2018 March 24-26, 2018 Singapore. ISBN 978-1-5386-5234-3

7. Dahlin J., Nelles M., Herbes C. 2017. Biogas digestate management: Evaluating the attitudes and perceptions of German gardeners towards digestate-based soil amendments. Resources, Conservation and Recycling 118, 27-38.

8. DIN 38 414/S8, 1985, Bestimmung des Faulverhaltens Schlamm und Sedimente, Beuth Verlag, Berlin

9. Kratzeisen M., Starcevic N., Martinov M., Maurer C., Müller J. 2010. Applicability of biogas digestate as solid fuel. Fuel 89, 2544-2548. 
10. Kozłowski K., Mazurkiewicz J., Chełkowski D., Jeżowska A., Cieślik M., Brzoski M., Smurzyńska A., Dongmin Y., Wei Q. 2018. The Effect of Mixing During Laboratory Fermentation of Maize Straw with Thermofilic Technology. Journal of Ecological Engineering 19(5), 93-98.

11. Kozłowski K., Lewicki A., Sołowiej P., Neugebauer M., Smurzyńska A. 2016. Usage of waste whey as mono-substrate in continuous fermentation process. Energy And Clean Technologies Conference Proceedings, SGEM 2016, Vol III, 345-355.

12. Latawiec A.E., Królczyk J.B., Kuboń M., Szwedziak K., DrosikA., Polańczyk E., Grotkiewicz K., Strassburg, B.B.N. 2017. Willingness to adopt biochar in agriculture: The producer's perspective. Sustainability 9(4): 655.

13. Neugebauer M. 2018. The use of biological waste as a source of low-temperature heat for hotbeds in spring in north-eastern Poland. Journal of Environmental Management 225, 133-138.

14. Regulation of the Minister for the Environment of 9 December 2014 On Waste Catalog (Dz.U. 2014 poz. 1923).

15. Ronga D., Setti L., Salvarani C., De Leo R., Bedin E. Pulvirenti A., Milc J., Pecchioni N., Francia E. 2019. Effects of solid and liquid digestate for hydroponic baby leaf lettuce (Lactuca sativa L.) cultivation. Scientia Horticulturae 244, 172-181.

16. Sowinska, A.; Pawlak, M.; Mazurkiewicz, J.; Pa- cholska, M. 2018. Comparison of the Results from Microscopic Tests Concerning the Quality of Activated Sludge and Effluent. Water 2017, 9(12), 918.

17. Tampio E., Ervasti S., Rintala J. 2015. Characteristics and agronomic usability of digestates from laboratory digesters treating food waste and autoclaved food waste. Journal of Cleaner Production 94, 86-92.

18. Verein Deutscher Ingenieure - VDI 4630 - Fermentation of organic materials. Characterisation of the substrate, sampling, collection of material data, fermentation tests. 2016.

19. Węglarzy K., Skrzyżala I., Stekla J., Matros B. 2017. Production, economic and environmental effect of agricultural biogas plant in Kostkowice. Journal of Agribusiness and Rural Development 2(44), 471-479.

20. Wojcieszak D., Przybył J., Myczko R., Myczko A. 2018. Technological and energetic evaluation of maize stover silage for methane production on technical scale. Energy 151, 903-912.

21. Zaborowicz M., Wojcieszak D., Górna K., Kujawa S., Kozłowski R.J., Przybył K., Mioduszewska N., Idziaszek P., Boniecki P., 2016. Determination of dry matter content in composted material based on digital images of compost taken under mixed visible and UV-A light. Proc. SPIE 10033, Eighth International Conference on Digital Image Processing (ICDIP 2016), 100332G (August 29, 2016); doi: $10.1117 / 12.2243985$. 